\title{
CRESCIMENTO E ACUMULAÇÃO DE SOLUTOS EM FEIJÃO-DE-CORDA IRRIGADO COM ÁGUAS DE SALINIDADE CRESCENTE EM DIFERENTES FASES DE DESENVOLVIMENTO
}

\section{AMANDA SORAYA FREITAS CALVET ${ }^{1}$; CIRO DE MIRANDA PINTO ${ }^{2}$; REIVANY EDUARDO MORAIS LIMA ${ }^{3}$; REBECA PERES MORENO MAIA-JOCA ${ }^{4}$ E MARLOS ALVES BEZERRA ${ }^{5}$}

${ }^{1}$ Departamento de Fitotecnia, Universidade Federal de Ceará, CE, agroamanda@yahoo.com.br

${ }^{2}$ Departamento de Fitotecnia, Universidade Federal de Ceará, CE, ciroagron@gmail.com

${ }^{3}$ Departamento de Engenharia Agrícola, CE, reivany_eduardo@hotmail.com

${ }^{4}$ Instituto Superior de Ciências Biomédicas, Universidade Estadual do Ceará, CE rebeca.maia@gmail.com

${ }^{5}$ Embrapa Agroindustria Tropical,CE, marlos@cnpat.embrapa.br

\section{RESUMO}

Este trabalho teve por objetivo estudar os efeitos da aplicação de água $\left(\mathrm{CEa}=0,5 \mathrm{dS} \mathrm{m}^{-1}\right)$ e/ou solução salina $\left(\mathrm{CEa}=5,0 \mathrm{dS} \mathrm{m}^{-1}\right)$, alternadamente, nas duas fases iniciais de desenvolvimento do feijão de corda cv. Epace 10. O experimento foi realizado, em condições de ambiente protegido (telado), na Embrapa Agroindústria Tropical. As sementes foram colocadas em vasos com capacidade para $15 \mathrm{~L}$ dispostos em um delineamento de blocos ao acaso, com 4 tratamentos e quatro repetições. As plantas foram submetidas aos tratamentos: 1. irrigação com água até o final da fase II; 2. irrigação com solução salina até o final da fase II, 3. irrigação com água até o final da fase I e solução salina até o final da fase II e 4. Irrigação com solução salina até o final da fase I e água até o final da fase II, momento em que os dados foram coletados. O crescimento não foi afetado pela aplicação de solução salina, independente da fase aplicada. Nos solutos compatíveis verificou-se redução nos teores de proteínas.

PALAVRAS-CHAVE: Vigna unguiculata L. estresse salino, crescimento

\author{
CALVET, A. S. F.; PINTO, C. de M.; LIMA, R. E. M.; MAIA-JOCA, R. P. M.; \\ BEZERRA, M. A. \\ GROWTH AND SOLUTE ACCUMULATION IN COWPEA IRRIGATED WITH \\ WATERS RISING SALINITY IN DIFFERENT STAGES OF DEVELOPMENT
}

\section{ABSTRACT}

This work aimed to study the effects of application of water $\left(\mathrm{CEw}=0,5 \mathrm{dS} \mathrm{m}^{-1}\right)$ and saline solution $\left(\mathrm{CEw}=5,0 \mathrm{dS} \mathrm{m}^{-1}\right)$ on the two initial stages of cowpea (cv. Epace 10) development. The experiment was performed in greenhouse environmental conditions at EMBRAPA Agroindústria Tropical. The seeds were placed in vessels with $15 \mathrm{~L}$ capacity and arranged in randomized blocks design with four treatments and four replications. The plants were subjected to treatments: 1 . 
Irrigation with water until the end of phase II; 2. Irrigation with saline solution until the end of phase II; 3. Irrigation with water until the end of phase I and saline solution until the end of phase II; 4. Irrigation with saline solution until the end of Phase I and water until the end of phase II. The plant growth was not affected by application of saline solution, regardless the applied phase. In the compatible solutes it was found a decrease in protein levels.

KEYWORDS: Vigna unguiculata L. saline stress, growth

\section{INTRODUÇÃO}

As sementes maduras do feijão-de-corda apresentam 22\% de proteína, $2 \%$ de lipídios e $60 \%$ de carboidratos (Vaughan \& Geissler, 2009). É um alimento básico na alimentação das populações mais pobres, exercendo importante função social no suprimento das necessidades nutricionais dessa camada, além de desempenhar papel fundamental na composição da produção agrícola brasileira, particularmente do Nordeste (Cordeiro et al., 1998). Em adição, a espécie apresenta vantagens para seu cultivo, como o ciclo curto e baixa demanda hídrica (Embrapa, 2003).

A produtividade da agricultura de regiões áridas e semiáridas é limitada por fatores de ordem abiótica, como a salinidade (Ashraf, 2004). A salinidade causa efeitos adversos no crescimento vegetal, em decorrência do potencial osmótico, estresse salino, desbalanço nutricional ou interação entre fatores (Marschner, 2012). Assim a compreensão do comportamento morfofisiológico das plantas cultivadas sob a influência da salinidade, deve-se constituir em ferramenta auxiliar aos programas de melhoramento vegetal bem como balizador do manejo de espécies cultivadas.

Maas \& Hoffman (1977) reportam que o feijão de corda é moderadamente sensível ao estresse salino. Outros autores consideram-na moderadamente tolerante à salinidade (Ayres; Westcot, 1999; Assis Júnior et al., 2007). O ajustamento ao estresse salino varia com o estádio de desenvolvimento da planta, o que pode possibilitar o cultivo em áreas que possuam águas de qualidade diferencial, ou nas áreas onde o teor salino das águas aumente durante o ciclo produtivo das culturas ou nos estádios mais tolerantes à salinidade (Rhoades et al., 2000). Assim, diversos estudos foram conduzidos com a utilização de soluções salinas na fase vegetativa (Prisco, 1987; Amador et al., 2006), na fase de floração (Enéas Filho et al., 2002; Ferreira, 2005) e em todo o seu ciclo (Assis Junior, 2007; Guimarães, 2005).

Com base no exposto, este trabalho teve por objetivo avaliar e estudar os efeitos da irrigação com águas de salinidade crescentes fornecidas alternadamente ou não, nas fases de crescimento inicial do feijão-de-corda, sobre o crescimento e o acúmulo de solutos orgânicos e inorgânicos na matéria seca das plantas.

\section{MATERIAL E MÉTODOS}

O experimento foi conduzido em ambiente protegido, na Embrapa Agroindústria Tropical, Fortaleza-CE $\left(3^{\circ} 45^{\prime} 5^{\prime \prime} \mathrm{S} ; 38^{\circ} 34^{\prime} 33^{\prime} \mathrm{W}\right)$, no período de julho a setembro de 2008 . O feijão-decorda EPACE 10 [Vigna unguiculata (L.) Walp)], foi semeado em vasos com capacidade de 15L, 
contendo solo de textura arenosa e não salino, saturado com água $\left(\mathrm{CEa}=0,5 \mathrm{dS} \mathrm{m}^{-1}\right)$ ou com solução salina $\left(\mathrm{CEa}=5,0 \mathrm{dS} \mathrm{m}^{-1}\right)$, composta de $\mathrm{NaCl}, \mathrm{CaCl}_{2} \cdot 2 \mathrm{H}_{2} \mathrm{O}$ e $\mathrm{MgCl}_{2} \cdot 6 \mathrm{H}_{2} \mathrm{O}$, na proporção de 7:2:1, respectivamente. O volume diário de água ou solução salina aplicado variou de $400 \mathrm{a}$ $600 \mathrm{~mL}$, dependendo da quantidade de água necessária para se atingir a capacidade de campo do solo dos vasos. A germinação ocorreu três dias após a semeadura e o desbaste foi realizado quatro dias após, deixando-se duas plantas por vaso. Durante o período experimental, as plantas receberam solução nutritiva (Hoagland \& Arnon, 1950) em três momentos: aos 15, 30 e 40 dias após a semeadura (DAS).

Os tratamentos aplicados foram os seguintes: 1- Irrigação das plantas com água de CEa de $0,5 \mathrm{dS} \mathrm{m}^{-1}$ do início da FASE I (da emergência das plântulas até o aparecimento da primeira folha trifoliolada) até o final da FASE II (do aparecimento da primeira folha trifoliolada até o início da floração); 2- Irrigação das plantas com solução salina de CEa de 5,0 dS m$~^{-1}$ até o final da FASE II; 3- Irrigação com água de CEa de $0,5 \mathrm{dS} \mathrm{m}^{-1}$ durante a FASE I, seguindo-se de irrigação com solução salina de CEa de $5,0 \mathrm{dS} \mathrm{m}^{-1}$ durante a FASE II; 4- Irrigação com solução salina de CEa de 5,0 dS m${ }^{-1}$ durante a FASE I, seguindo-se de irrigação com água de CEa de $0,5 \mathrm{dS} \mathrm{m}^{-1}$ durante a FASE II. O delineamento estatístico adotado foi o inteiramente casualizado, com 4 tratamentos e 4 repetições.

As medidas de crescimento foram realizadas ao final da FASE II. As medições tomadas foram altura e contagem do número de folhas, seguido da coleta das plantas, as quais foram separadas em folhas, ramos+pecíolos e raízes. Após, a área foliar foi determinada mediante o uso de um integrador de área (LI-3100, Área Meter, Li-Cor.,Inc.,Lincoln, Nebrasca, USA). Em seguida, as partes das plantas foram colocadas para secar em estufa com circulação de ar por 72 horas, quando se determinou a massa da matéria seca de cada órgão das plantas.

Os teores de solutos inorgânicos como o Na, Cl, e K foram determinados na matéria seca, após a maceração em almofariz do material vegetal utilizado. Homogeneizou-se $1 \mathrm{~g}$ do material em $50 \mathrm{~mL}$ de água desionizada, passada através de filtros miliporos (mili-Q). Em seguida, essa mistura foi submetida à agitação por 2 horas e filtrada em papel de filtro do tipo lento. $\mathrm{O}$ extrato obtido foi mantido em refrigerador à temperatura de $-2^{0} \mathrm{C}$ até a realização das análises (Miyazawa et al., 1984).

Os teores de $\mathrm{Na}$ e $\mathrm{K}$ foram determinados por fotometria de chama, após diluição do extrato em água deionizada e filtrada (mili-Q). Para a determinação do cloreto, ao extrato diluído adicionou-se, sob agitação, uma mistura de $0,5 \mathrm{~mL}$ do reagente $\mathrm{Hg}(\mathrm{SCN})_{2}-\mathrm{Fe}\left(\mathrm{NO}_{3}\right)$. Em seguida, essa mistura foi mantida em repouso por 15 minutos. $\mathrm{O}$ teor de cloreto foi determinado em espectrofotômetro usando filtro de comprimento de onda de 460nm (Gaines et al., 1984).

Para a determinação dos solutos orgânicos, amostras das partes da planta (folha, caule + pecíolo e raiz) foram coletadas, cortadas em pequenos pedaços e protegidas por envelopes de papel alumínio perfurado e em seguida congeladas. Sendo depois liofilizadas.

O extrato base para determinação dos solutos orgânicos foi obtido a partir da maceração, em almofariz, de $200 \mathrm{mg}$ do tecido liofilizado e $4,0 \mathrm{~mL}$ de tampão fosfato de potássio a $100 \mathrm{mM}$, $\mathrm{pH} 7,6$. O macerado foi filtrado em tecido de náilon de malha fina e centrifugado a $15.000 \times \mathrm{g}$ durante $15 \mathrm{~min}$. Todos os procedimentos foram conduzidos à temperatura ambiente e o sobrenadante (extrato) foi armazenado a $-25^{\circ} \mathrm{C}$ até o momento das análises (Guimarães, 2005).

Os carboidratos solúveis foram determinados pelo método desenvolvido por Dubois et al. (1956). Foi adicionado a cada tubo de ensaio o extrato diluído em fenol a 5\% e ácido sulfúrico concentrado, seguido de agitação vigorosa da mistura e repouso em bandeja contendo água á 
$25^{\circ} \mathrm{C}$ por 20 minutos. Os carboidratos solúveis foram quantificados em espectrofotômetro a 490 $\mathrm{nm}$, sendo usado a $\mathrm{D}(+)$ glicose anidra como padrão e os resultados expressos em $\mu \mathrm{mol}$ de carboidratos $\mathrm{gMS}^{-1}$.

A concentração de compostos $\mathrm{N}$-aminossolúveis foi determinada pelo método de Yemm $\&$ Cocking (1955). Em tubos de ensaio, foram adicionados: $500 \mu \mathrm{L}$ do extrato devidamente diluído em água, $250 \mu \mathrm{L}$ do tampão citrato $0,2 \mathrm{M}, 500 \mu \mathrm{L}$ do $\mathrm{KCN} 0,2 \mathrm{mM}$ e $100 \mu \mathrm{L}$ de ninhidrina a 5\%. Os tubos foram agitados e depois colocados em banho-maria por 20 minutos, a $100{ }^{\circ} \mathrm{C}$. Após, a reação foi interrompida por resfriamento dos tubos em banho de gelo. Em seguida, foi adicionado etanol para a fixação da cor desenvolvida (violeta). A leitura foi realizada em espectrofotômetro a $570 \mathrm{~nm}$, usando o aminoácido L-glicina como padrão. Os resultados foram expressos em $\mu \mathrm{mol}$ aminoácidos $\mathrm{g} \mathrm{MS}^{-1}$.

Para a determinação de proteínas solúveis, utilizou-se o método desenvolvido por Bradford (1976). Para determinação do teor de proteínas misturou-se $100 \mu \mathrm{L}$ do extrato diluído em água com $1 \mathrm{~mL}$ do reagente de Bradford. As leituras foram feitas em espectrofotômetro a 595 $\mathrm{nm}$, realizadas entre 10 e 20 min após a adição do reagente. A albumina sérica bovina (BSA) foi utilizada como padrão.

\section{RESULTADOS E DISCUSSÃO}

Analisando-se a área foliar e número de folhas das plantas, constata-se que os tratamentos salinos não proporcionaram alterações significativas no crescimento (Figura 1A e $1 \mathrm{C}$ ). Vale destacar que a salinidade causa geralmente, redução na emissão de folhas, em decorrência da redução do potencial osmótico da solução do solo, consequentemente diminui a disponibilidade de água pelas raízes (Jacome et al., 2005). Por sua vez, Enéas Filho et al. (2002), estudando o feijão-de-corda submetido a salinidade nas fases iniciais, demonstraram que a solução salina proporcionou apenas uma pequena inibição no desenvolvimento das raízes, caules e folhas da cultivar Pitiúba. Outros autores porém observaram com o feijão-de-corda nas suas fases iniciais, resultados divergentes aos encontrados no presente trabalho, com a salinidade tendo redução no desenvolvimento das plantas (Dantas et al., 2002; Lima et al., 2007; Neves et al., 2009).
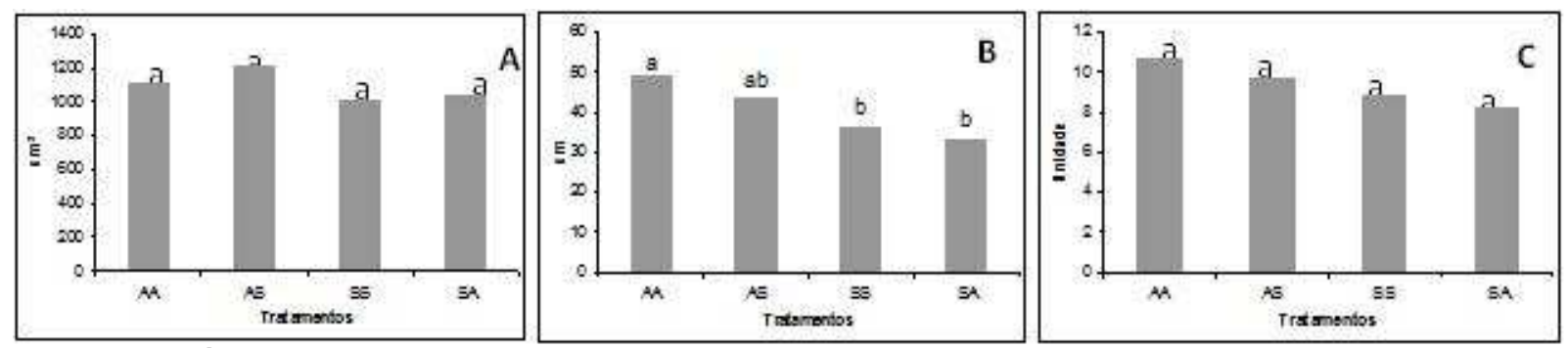

Figura 1. Área foliar (A), altura (B) e número de folhas (C) de plantas de feijão de corda submetidas a salinidade, durante duas fases vegetativas. Tratamentos- AA (águaagua); AS (água-sal); SS (sal-sal); AS (sal-agua). Colunas seguidas com a mesma letra não diferem entre si pelo teste de Tukey a 5\% de probabilidade. 
Com relação à altura da planta do feijão-de-corda, constatou-se que a FASE II não teve alteração pela adição dos sais (Figura 1B). Silva et al. (2009) trabalhando com feijão-de-corda, observaram que a altura de planta decresceu linearmente com aumento da salinidade da solução do solo. Lima et al. (2012) detectaram que a altura das plantas de mamona decresceu com incrementos dos níveis de salinidade na água de irrigação.

A matéria seca das folhas, ramos + pecíolos e raízes, apresentaram ausência de significância entre tratamentos, sugerindo que as modificações na estrutura da planta tiveram a mesma magnitude (Figuras 2A, 2B e 2C). Çiftçi et al. (2011), estudando o feijão comum reportaram redução da matéria seca da parte aérea e raiz dos genótipos submetidos a salinidade.
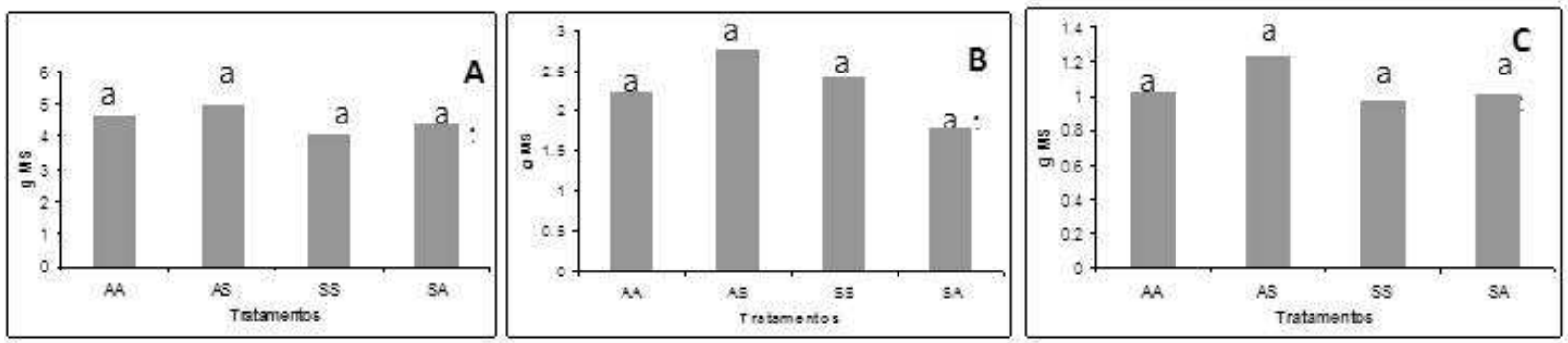

Figura 2. Matéria Seca das folhas (A), ramos (B) e raízes (C) de plantas de feijão de corda submetidas à salinidade durante duas fases vegetativas. Tratamentos-AA (água-agua); AS (água-sal); SS (sal-sal); SA(sal-agua). Colunas seguidas com a mesma letra não diferem entre si pelo teste de Tukey a $5 \%$ de probabilidade.

O teor de cloreto aumentou devido à salinidade em todos os órgãos analisados, com esse aumento sendo mais proeminente nas plantas que receberam solução salina durante todo o período experimental (Figuras 3A, 3B e 3C).
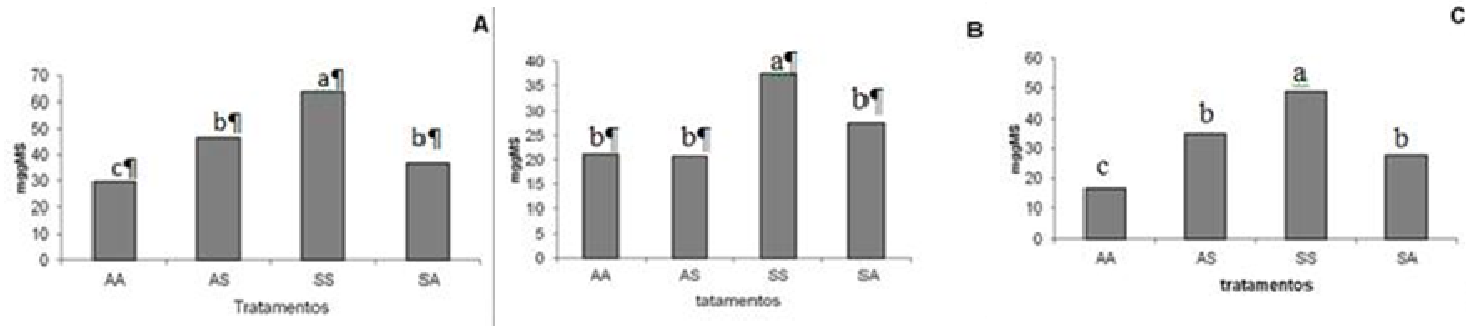

Figura 3. Teor de cloreto nas folhas (A), ramos (B) e raízes (C) de plantas de feijão de corda submetidas a salinidade, durante duas fases vegetativas. Tratamentos- AA (águaagua); AS(água-sal); SS(sal-sal); SA(sal-agua). Colunas seguidas com a mesma letra não diferem entre si pelo teste de Tukey a $5 \%$ de probabilidade.

O teor de sódio não apresentou diferenças significativas nas folhas e raízes, enquanto para o caule resultou em aumento significativo desse íon principalmente no tratamento que recebeu solução salina durante todo o período experimental (Figuras 4A, 4B e 4C), indicando retenção de sódio no caule (Silva et al., 2011; Neves et al., 2009). Santos et al. (2009), pesquisando a resposta do feijoeiro a salinidade, constataram que o teor de sódio decrescem na sequência de caule $>$ raízes $>$ pecíolos $>$ folhas, indicando capacidade das plantas em diminuir a concentração 
deste elemento nos órgãos fotossinteticamente ativos, fator positivo na definição da tolerância ao estresse salino.
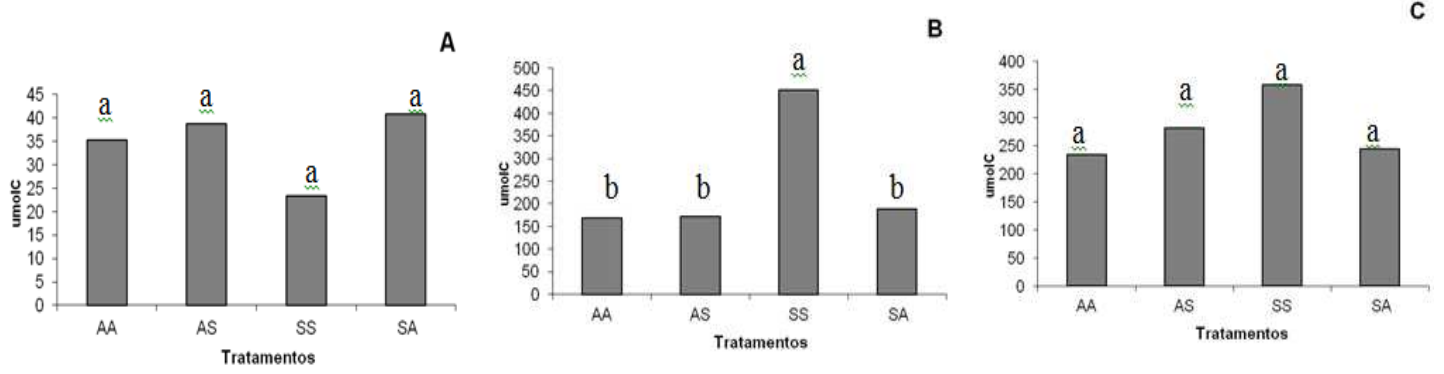

Figura 4 . Teor de sódio nas folhas (A), ramos (B) e raízes (C) de plantas de feijão-de-corda submetidas à salinidade durante duas fases vegetativas. Tratamentos- AA (águaagua); AS (água-sal); SS (sal-sal); AS (sal-agua). Colunas seguidas com a mesma letra não diferem entre si pelo teste de Tukey a $5 \%$ de probabilidade.

Assis Júnior et al. (2007), analisando a influência da salinidade no acúmulo do íon sódio nas folhas de plantas de feijão-de-corda, perceberam que durante as duas fases iniciais de desenvolvimento da planta, o valor do íon sódio não apresentou diferença entre os tratamentos, aumentando significativamente na fase final. Sousa et al. (2007), estudando o efeito da salinidade em plantas de feijão-de-corda constatou um efeito significativo nos teores de $\mathrm{Na}$ e $\mathrm{Cl}$ no caule. Já nas folhas, a salinidade influenciou apenas os teores de cloreto.

$\mathrm{O}$ emprego da água salina independentemente da fase resultou em menores teores de $\mathrm{K}$ nas raízes, mas não interferiu significativamente nos teores acumulados nas folhas e ramos. Essa situação indica que o aumento da salinidade da água não prejudicou a dinâmica e $\mathrm{K}$ das raízes para os demais órgãos (Figuras 5A, 5B e 5C). A competição entre os íons $\mathrm{Na}$ e $\mathrm{K}$ pelos mesmos transportadores na membrana pode reduzir a absorção desse último. Entretanto, esta relação antagônica, verificada em muitas espécies (Lacerda et al., 2003; Garcia et al., 2007) não tem sido observada na maioria das cultivares de feijão-de-corda (Costa et al., 2003).

A

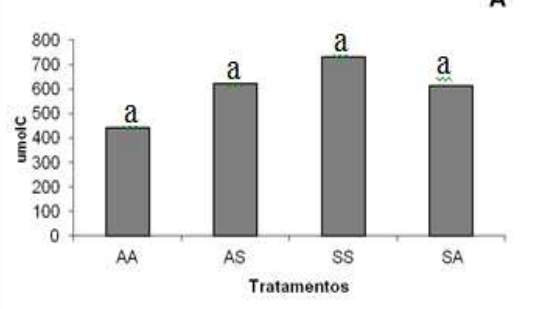

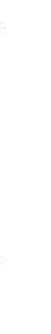

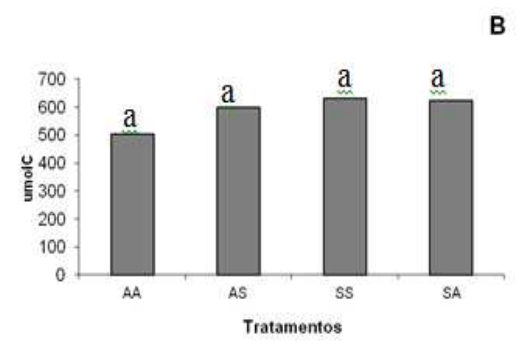

B

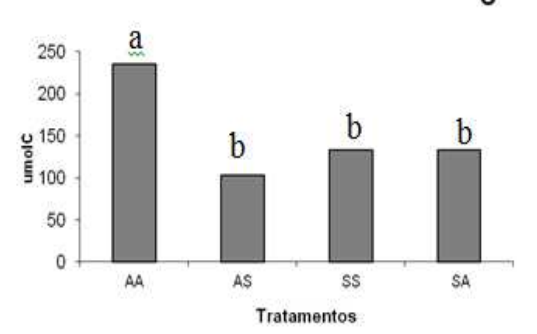

Figura 5. Teor de potássio nas folhas (A), ramos (B) e raízes (C) de plantas de feijão de corda submetidas à salinidade durante duas fases vegetativas. Tratamentos- AA(água-agua); AS(água-sal); SS(sal-sal); SA(sal-agua). Colunas seguidas com a mesma letra não diferem entre si pelo teste de Tukey a $5 \%$ de probabilidade. 
$\mathrm{O}$ incremento da salinidade da água não exerceu respostas significativas nos teores de carboidratos nas folhas, ramos e raízes de plantas de feijão-de-corda (Figuras 6A, 6B e 6C). Situação semelhante foi registrada por Azevedo Neto et al. (2004). Abreu et al. (2008) \& Amorim et al. (2010) após verificarem que a irrigação com águas salinas não inibiu a produção de carboidratos solúveis em plantas de milho e de cajueiro anão precoce, respectivamente. Estudos desenvolvidos por Silva et al. (2003) \& Oliveira et al. (2006) reportaram aumento desse soluto em função da salinidade. Geigenberger et al.(1997) relataram que esse comportamento pode ser resultante da inibição da síntese do amido, bem como pelo aumento em sua degradação produzindo açúcares solúveis.
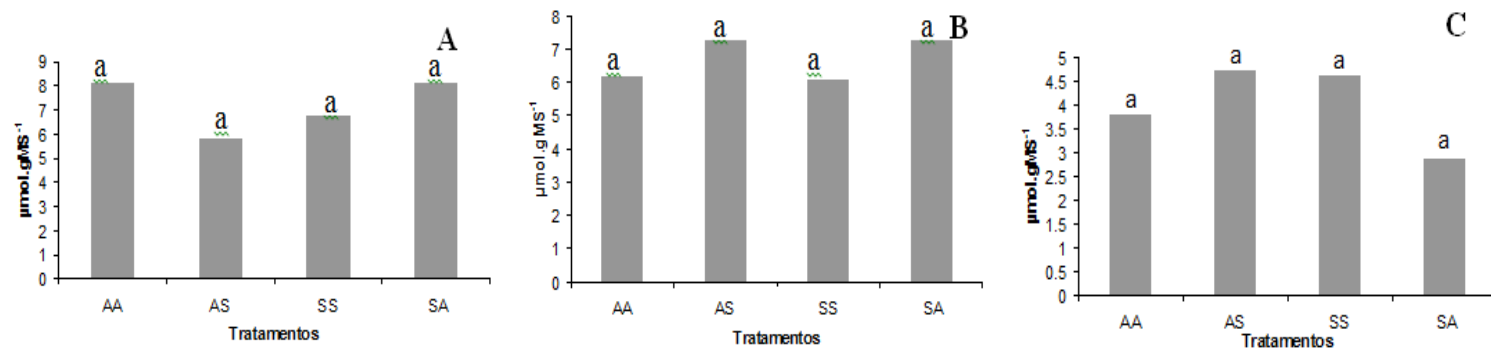

Figura 6. Teores de carboidratos na folhas (A), ramos (B) e raízes $(C)$ de plantas de feijão de corda submetidas à salinidade durante duas fases vegetativas. Tratamentos- AA (água-agua); AS (água-sal); SS (sal-sal); SA (sal-agua). Colunas seguidas com a mesma letra não diferem entre si pelo teste de Tukey a 5\% de probabilidade.

Com relação ao feijão-de-corda, também foram observados resultados conflitantes em função da salinidade, com as concentrações de carboidratos mantendo-se inalterados (Costa et.al., 2003; Souza et al., 2011) ou aumentadas (Franco et al., 1999). Praxedes (2008), analisando o efeito da salinidade nessa cultura observou que o teor dos carboidratos totais variou conforme a época da coleta, parte da planta (raiz e folha) e cultivar utilizada.

Os teores de aminoácidos nas folhas e raízes não foram afetados significativamente pela salinidade imposta nos diferentes tratamentos (Figuras 7A e 7C). Por sua vez, o teor desse soluto nos ramos foi aumentado nas plantas de todos os tratamentos com água salina (Figura 7B). Resultado semelhante também foi observado por Abreu (2004), ao constatar aumentos dos teores de aminoácidos em folhas e raízes de plântulas de cajueiro anão precoce submetidas à salinidade. Praxedes et al. (2009) observaram aumento nos teores de aminoácidos nas folhas e raízes do feijão de corda na cultivar mais sensível aos 24 DAS, mostrando também que a época e o genótipo influenciou no acúmulo deste soluto. 

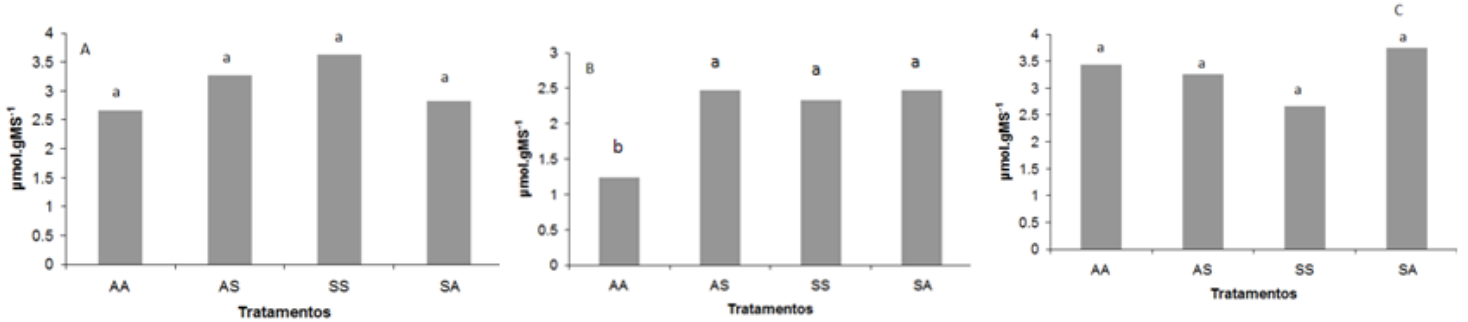

Figura 7. Teores de aminoácidos nas folhas (A), ramos (B) e raízes $(C)$ de plantas de feijão de corda submetidas à salinidade durante duas fases vegetativas. Tratamentos- AA(águaagua); AS(água-sal); SS(sal-sal); SA(sal-agua). Colunas seguidas com a mesma letra não diferem entre si pelo teste de Tukey a $5 \%$ de probabilidade.

Os teores de proteínas foram afetados significativamente pela aplicação das soluções salinas. Nas folhas, o tratamento que recebeu sal nas duas fases vegetativas apresentou menor teor que os demais (Figura 8A). Nos ramos, a aplicação alternada de água e sal, independente da sequência de aplicação, provocou redução nos teores de proteínas (Figura 8B), enquanto nas raízes as proteínas só foram afetadas quando as plantas receberam sal nas duas fases vegetativas (Figura 8C).
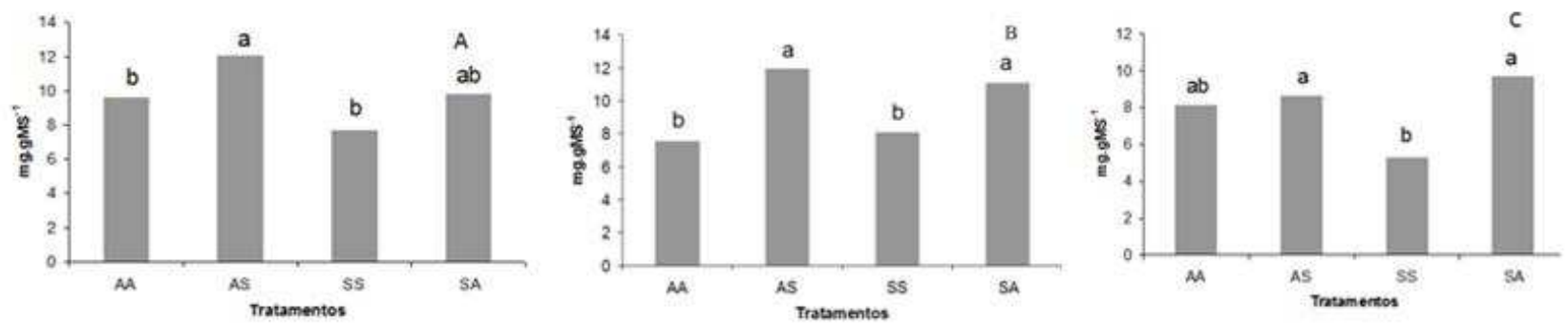

Figura 8. Teores de proteínas nas folhas (A), ramos (B) e raízes $(C)$ de plantas de feijão de corda submetidas à salinidade durante duas fases vegetativas. AA(água-agua); AS(água-sal); SS(sal-sal); AS (sal-agua). Colunas seguidas com a mesma letra não diferem entre si pelo teste de Tukey a $5 \%$ de probabilidade.

A síntese de proteínas geralmente diminui em condições de estresse salino. Silveira et al.(2003) mencionaram que o excesso de sais prejudica a síntese proteica e eleva a proteólise e as células também sintetizam proteínas específicas sob condições de estresse. Vários genes codificam enzimas envolvidas na fotossíntese, na síntese de solutos compatíveis, na proteção contra danos oxidativos ou codificam proteínas envolvidas no sequestro vacuolar de íons tóxicos, aumentando assim o seu teor (Parida \& Das, 2005; Mansour, 2000).

\section{CONCLUSÃO}

O crescimento não foi afetado pela aplicação de solução salina, independente da fase aplicada. 
Nos solutos compatíveis verificou-se redução nos teores proteínas.

\section{REFERÊNCIAS BIBIOGRÁFICAS}

ABREU, C. E. B. de. Crescimento, osmorregulação e mobilização de reservas em plântulas de cajueiro anão-precoce submetidas à salinidade. 2004. 60 f. Monografia (Graduação em Biologia) Universidade Federal do Ceará, Fortaleza, 2004.

ABREU, C. E. B. de et al. Physiological and biochemical changes occurring in dwarf-cashew subjected to salt stress. Brazilian Journal of Plant Physiology, v. 20, n.2, p. 105-118, 2008.

AMORIM, A. V. et al. Respostas fisiologicas de plantas adultas de cajueiro anão precoce a salinidade. Revista Ciencia Agronômica, v. 41, n.1, p. 113-121, 2010.

AMADOR, B. M. et al. Effect of $\mathrm{NaCl}$ salinity in the genotypic variation of cowpea (Vigna unguiculata) during early vegetative growth. Scientia Horticulturae, v.108, n.4, p.423-431, 2006.

ASHRAF, M. Some important physiological selection criteria for salt tolerance in plants. Flora, v.199, n.5, p.361-376, 2004.

ASSIS JÚNIOR, J. O. et al. Produtividade do feijão-de-corda e acúmulo de sais no solo em função da fração de lixiviação e da salinidade da água de irrigação. Engenharia agrícola, v. 27, n.3, p. 702-713, 2007.

ASSIS JÚNIOR, J. O. Produtividade do feijão-de-corda e acúmulo de sais no solo em função da salinidade da água e da fração de lixiviação. 2007. 63 f. Dissertação (Mestrado em irrigação e drenagem) Universidade Federal do Ceará, Fortaleza, 2007.

AYERS, R. S.; WESCOT, D. W. A qualidade da água agricultura. Campina Grande: UFPB, 1999. $153 \mathrm{p}$.

AZEVEDO NETO, A. D. et al. Effects of salt stress on plant growth, stomatal response and solute accumulation of different maize genotypes. Journal of Plant Physiology, v. 16, n.1, p.3138. 2004.

BRADFORD, M. M. A rapid and sensitive method for the quantitation of microgram quantities of protein utilizing the principle of protein-dye binding. Analytical Biochemistry, v. 72, p. 248254, 1976.

ÇIFTÇI, V. et al. Variation of salinity tolerance in bean genotypes. African Journal of Agricultural Research,v.6, n.10, p. 2394-2402, 2011. 
CORDEIRO, L. G.; BEZERRA, F. M. L.; SANTOS, J. J. A. dos; MIRANDA, E. P. de. Fator de sensibilidade ao déficit hídrico da cultura do feijão caupi (Vigna unguiculata (L.) WALP.). Revista Brasileira de Engenharia Agrícola e Ambiental, v.2, n.2, p.153-157, 1998.

COSTA, P. H. A. et al. Crescimento e níveis de solutos orgânicos e inorgânicos em cultivares de Vigna unguiculata submetidos à salinidade. Revista Brasileira de Botânica, v. 26, n.3, p.289297, 2003.

DANTAS, J.P. et al. Avaliação de genótipos de caupi sob salinidade. Revista Brasileira de Engenharia Agrícola e Ambiental, v.6, n.3, p.425-430, 2002.

DUBOIS, M.. et al. Colorimetric method for determination of sugars, and related substances. Analytical Chemistry, v. 28, n.3, p.350-356, 1956.

EMPRESA BRASILEIRA DE PESQUISA AGROPECUÁRIA - EMBRAPA. Cultivo de Feijão-Caupi: importância econômica. Versão Eletrônica, Janeiro de 2003.

ENÉAS FILHO, J. ; SUDÉRIO, F. B.; BARBOSA, G. K. C. ; SILVA, R. P. P. ; GOMESFILHO, E. ; PRISCO, J. T. Atividade beta-galactosidásica em parede celular de raízes, caules e folhas de Vigna unguiculata submetidas à salinidade. In: VI REUNIÃO REGIONAL DA SNNQ. Nordeste, 2002, Fortaleza (CE). CD-ROM, arquivo 008.pdf, 2002.

FERREIRA, M. C. da C. Efeito do sal no crescimento e metabolismo de Vigna unguiculata $L$. Walp e Vigna unguiculata(jacq) Benth. 2005, 74 f. Dissertação (mestrado em Biologia vegetal) Universidade Estadual de Campinas, Campinas, SP.

FRANCO, O. L. et al. Effects of $\mathrm{CaCl} 2$ on growth and osmoregulator accumulation in $\mathrm{NaCl}$ stressed cowpea seedlings. Revista Brasileira de Fisiologia Vegetal, v.11, n.3, p.145-151, 1999.

GAINES, T. P. et al Automated determination of chlorides in soil and plant tissue by sodium nitrate extration. Agronomy Journal, v. 76, n.3, p. 371-374, 1984.

GARCIA, G de O. et al. Teores foliares dos macronutrientes catiônicos e suas relações com o sódio em plantas de milho sob estresse salino. Idesia, vol.25, n.3, p. 93-106, 2007.

GEIGENBERGER, P. et al. Regulation of sucrose and starch metabolism in potato tubersin response to short term water-deficit. Planta, v. 201, n. 4, p. 502-518, 1997.

GUIMARÃES, F. V. Respostas fisiológicas e bioquímicas em plantas de feijão-de-corda cv. Pitiúba submetidas ao estresse com $\mathrm{NaCl}$ em diferentesconcentrações de $\mathrm{CaC2}$ e CaSO4. 2005. 176 f. Tese (Doutorado em Bioquímica Vegetal). Universidade Federal do Ceará, Fortaleza.

HOAGLAND, D.; ARNON, D. I. The water culture method for growing plants without soil. circular 347. Berkeley: University of Califórnia Agricultural Experiment Station, 1950. p.1-32. 
JACOME, A. G. et al. Tolerância do algodoeiro em diferentes estádios irrigado com água salina. In: CONGRESSO BRASILEIRO DE ALGODÃO, 5.,2005. Paraíba. Anais... Paraíba: EMBRAPA, 2005. CD Room.

LACERDA, C. F. et al. Solute accumulation and distribution during shoot and leaf development in two sorghum genotypes under salt stress. Environmental and Experimental Botany, v. 49, n. 2, p 107-120, 2003.

LIMA, C. J. G. de S. et al. Resposta do feijão caupi a salinidade da água de irrigação. Revista Verde, v. 02, n.2, p.79-86, 2007.

LIMA, G. S. et al. Utilização de águas salinas e doses de adubação nitrogenada no cultivo da mamoneira cv. BRS Energia. Revista Verde de Agroecologia e Desenvolvimento Sustentável, v. 7, n. 2, p.88-95, 2012.

MAAS, E. V.; HOFFMAN, G. J. Crop salt tolerance - current assessment. Journal of Irrigation and Drainage Division, v. 103, p.115-134, 1977.

MANSOUR, M. M. F. Nitrogen containing compounds and adaptation of plants to salinity stress, Biology Plantarum, v. 43, p. 491-500, 2000.

MARSCHNER, H. Mineral nutrition of higher plants. Third edition. London: Academic Press, 2012. $651 \mathrm{p}$.

MIYAZAWA, M. et al. Avaliação de métodos com e sem digestão para extração de elementos em tecidos de plantas. Ciência e Cultura, v. 36, n.11, p. 1953-1958, 1984.

MUNNS, R. Comparative physiology of salt and water stress. Plant and Cell Environment, v. 25, p. 239-250, 2002.

NEVES, A. L. R. et al. Acumulação de biomassa e extração de nutrientes por plantas de feijãode-corda irrigadas com água salina em diferentes estádios de desenvolvimento. Ciência Rural, Santa Maria, v.39, n.3, p.758-765, 2009.

OLIVEIRA, L. A. A. et al. Solutos orgânicos em genótipos de sorgo forrageiro sob estresse salino. Pesquisa agropecuária brasileira. vol.41, n.1, p. 31-35, 2006.

PARIDA, A. K.; DAS, A. B. Salt tolerance and salinity effects on plants: a review.

Ecotoxicology and Environmental Saafey, v. 60, n. 03, p. 324-349, 2005.

PRAXEDES, S. C. Alterações fisiológicas e bioquímicas em dois cultivares de feijão-decorda com tolerância diferencial á salinidade. 145 f. 2008. Tese (Doutorado em fitotecnia), Universidade Federal do Ceará, Fortaleza, 2008.

PRAXEDES, S. C. et al. Acúmulo de prolina e aminoácidos em cultivares de feijão caupi com tolerância diferencial à salinidade. Caatinga, v.22, n.3, p. 211-214, 2009 . 
PRISCO, J. T. Contribuição ao estudo da fisiologia do estresse salino durante a germinação e estabelecimento da plântula de uma glicófita [Vigna unguiculata (L.) Walp.], 65 p.. 1987. (Tese Professor Titular de FisiologiaVegetal) Universidade Federal do Ceará, Fortaleza.

RHOADES, J. D.; KANDIAH, A.; MASHALI, A. M. Uso de águas salinas para produção agrícola. Campina Grande: UFPB, 2000. 117 p. (Estudos FAO. Irrigação e drenagem, 48).

SANTOS, P. R. et al. Acúmulo de cátions em dois cultivares de feijoeiro crescidos em soluções salinas. Revista Ceres, v. 56, n.5, p. 666-678, 2009.

SILVA, J. V. et al. Physiological response of $\mathrm{NaCl}$ stressed cowpea $\mathrm{NaCl}$ plants grown in nutrient solution supplemented with $\mathrm{CaCl}_{2}$. Brazilian Jornal of Plant Physiology, v. 15, n. 02, p. 99-105, 2003.

SILVA, F. E. O. et al. Desenvolvimento vegetativo do feijão caupi irrigado com água salina em casa de vegetação. Revista Caatinga, v.22, n3, p156- 159,2009.

Silva, F. L. B. et al. Interação entre salinidade e biofertilizante bovino na cultura do feijão-decorda. Revista Brasileira de Engenharia Agrícola e Ambiental, v.15, n.4, p.383-389, 2011.

SILVEIRA J.A.G. et al. Proline accumulation and glutamine synthetase are increased by saltinduced proteolysis in cashew leaves. Journal of Plant Physiology, v.160, n.2, p.115-123, 2003.

SOUZA, R. P. et al. Fotossíntese e acúmulo de solutos em feijoeiro caupi submetido à salinidade. Pesquisa Agropecuária Brasileira, v.46, n.6, p.586-592, 2011.

SOUSA, R. A. et al. Crescimento e nutrição mineral de feijão-de-corda em função da salinidade e composição iônica da água de irrigação. Revista Brasileira de Ciências Agrárias, v.2, n.01. p.75-82, 2007.

VAughan, J. G.; GEISSLER, C. A. Other Oil Producing Plants. In: The New Oxford Book of Food Plants, Oxford, University Press, 284 p, 2009.

TAIZ, L.; ZEIGER, E. Fisiologia vegetal. 4. ed. Porto Alegre: Artmed, 2009, 819 p.

YEMM, E. W.; COCKING, E. C. The determination of amino acids with ninhydrin. The Analyst, v. 80, n. 948, p. 209-213, 1955. 